\title{
Digital Community Social Capital: Case Study on Increasing the Popularity of Millennial Youtubers in Makassar City
}

\author{
Andry Wijaya ${ }^{1}$, Suparman Abdullah ${ }^{1}$, Rahmad Muhammad ${ }^{1}$ \\ Email: andry@gmail.com \\ Department of Sociology, Hasanuddin University, Makassar, Indonesia \\ Received: May 15, 2021 \\ Received in Revised: June 21, 2021 \\ Accepted: July 3, 2021
}

\begin{abstract}
One of the global developments that is fast and has quite an impact on the pattern of people's lives is developments in the field of technology and information, namely through the internet. YouTube has become an internet media that is in demand by various audiences around the world. Disbursing youtube adsense is fairly complicated, but the work as a youtuber is currently in great demand by Millennials. Youtuber is a new job that is synonymous with Millennials in this 4.0 industrial era. This study aims to determine the use of social capital trust by youtubers in increasing popularity, as well as to determine the use of social capital linking youtubers in increasing popularity. This study uses a qualitative approach, with informants namely millennial youtubers who live in the city of Makassar. Data collection techniques through observation, interviews and documentation, with data analysis techniques using: data reduction, data presentation and drawing conclusions and verification. The results of the study show that trust social capital is widely used by youtubers to increase their popularity, in this case increasing the number of subscribers and viewers on their youtube channel. Many YouTubers use social capital linking or networks to increase the number of subscribers and viewers. The social capital of the network used is by utilizing the friendship and community of YouTubers in the process of designing content, taking videos, editing to uploading videos and socializing YouTube channels in order to minimize the cost of managing YouTube channels for YouTubers.
\end{abstract}

Keywords: Social Capital, Trust, Network and Popularity

\section{Introduction}

The rapid development of the modern era has a significant influence on people's lives. Developments that occur globally make people are required to be able to compete in order to show their existence. One of the global developments that is fast and has quite an impact on the pattern of people's lives is the development in the field of technology and information. The phenomenon of this development is characterized by information that is so quickly obtained and distributed that it can even reach various parts of the world. In addition, the use of gadgets and an easily accessible internet connection makes people in this modern era want all matters to be resolved quickly.

The development of technology and information is quite rapid, it can be said that one of the targeted generations is those born around the 1980s - 2000s or commonly referred to as the millennial generation. Millennials are a cohort term in demographics which means followers or groups. Purwadi \& Ali (2017) argue that currently there are four large cohorts in demographics, namely Baby Boomers (born 1946-1964), Gen-X (born 1965-1980), Millennials (born 1981-2000), and Gen-Z (born 2001-present). The results of research released by the Pew Research Center clearly explain the characteristics of the Millennial generation compared to 
previous generations. One of the striking characteristics of the Millennial generation compared to previous generations is the use of technology and pop culture or music. Millennials cannot be separated from technology, especially the internet and entertainment, because it has become a basic need for them. It is undeniable, the majority of internet users are the millennial generation because they were born when internet technology was becoming known. A survey conducted by the IDN Research Institute in collaboration with the Alvara Research Center in 12 major cities in Indonesia entitled Indonesia Millenial Report 2019 shows that $94.4 \%$ of Indonesian millennials have been connected to the internet, even most of them have experienced addiction and even dependence on the internet.

The existence of the internet is considered to be very important when in its development social media also comes with various forms and functions. The facilities offered by social media also attract a lot of attention from mankind. This makes some social media to be superior with the number of users on a regular basis. From some of the social media above, which is of particular concern in terms of facilities and functions is Youtube. Youtube is one of the easiest means to appreciate talents and interests. Only with an internet network and a device or camera as a recording device, the video is ready to be launched and enjoyed by viewers. The phenomenon that has occurred recently is where a lot of people, both individuals and groups, have become " youtubers ". This also happened in Makassar City. Makassar City is one of the most important cities in economic development in Indonesia. The city continues to show very progressive growth from various sectors, the stretch of economic activity is felt. In addition to the conducive condition of the Government system, strategic position, as well as the growth of various varied economies and tourist attractions as well as infrastructure support that continues to be developed. For millennial youth in the city of Makassar, one of the fun jobs and can also be used as a source of creative economy is to become a YouTuber.

Youtuber is a term for a person or group who deliberately makes videos based on their respective fields and talents then the videos are uploaded via video sharing media, namely YouTube. Youtube serves as a means of sharing videos online. There are lots of videos uploaded on YouTube. Uploaded youtube videos can be classified into several classifications including vlogs, challenges, tutorials, reviews from various segments and react . YouTube has become an internet media that is in demand by various audiences around the world. Including one in Indonesia. In addition, YouTube can also be a new means of earning income. If there are a lot of subscribers (followers) and viewers (audiences) on YouTube, then the income or usually called adsense will also increase. Even though the disbursement of youtube adsense is quite complicated, the work as a youtuber is currently in great demand by Millennials. Youtuber is a new job that is synonymous with Millennials in this 4.0 industrial era.

Social capital can also be referred to as the ability of the community to have good relations with each other and subsequently become a very important force not only for economic life but also for every other aspect of social existence. This social capital can be seen from the main elements contained in it. Basic elements of social capital are, among others: participation in the network, resiprocity (reciprocity or exchange of kindness), trust (confidence or trust), social norms, values, and proactive measures.

If it is associated with youtubers, it can be said that social capital has an important role in supporting its popularity (Giles, 2018; Corrêa et al., 2020). Starting from the network of friends they have, mutual trust that is built between YouTubers (content creators) and subscribers or viewers (content lovers) and often there is a fairly close bond between YouTubers and their followers. The focus of the problem in this research is how to elaborate on the use of trust social capital and the use of social capital linking YouTubers in increasing popularity. 


\section{Literature Review}

The grouping of the younger generation that is being discussed a lot today, both in Indonesia and in various parts of the world, is the millennial generation (millennials). This generation is synonymous with technology, especially the internet and social media because it has become their basic need and most of them have social media. One of the interesting media related to the relationship between the millennial generation and social media is YouTube. They use YouTube to discuss anything, from trivial things, such as culinary issues, games, makeup, to things that are important to people's lives, such as the presidential election, content about literacy and so on.

Being a YouTuber is currently very interesting for the millennial generation. Many are the motives of their choice to become youtubers, some are economic motives, but there are also those who become youtubers because of the motive of wanting to become an artist and be famous. Whatever their motives, there are many things that must be prepared before deciding to become a YouTuber, one of which is social capital.

Social capital which has several components such as trust and linking is important for youtubers to have because with this social capital they can increase their subscribers and viewers which has an impact on their popularity. They can build a sense of trust and take advantage of the network of friends they have, this is done with the intention of increasing their popularity. However, researchers still feel the need to elaborate on the use of YouTubers' social capital in increasing their popularity.

A youtuber must also have social capital to increase their popularity. Social capital is not capital in the usual sense such as wealth or money, but rather has a figurative meaning, but is an important asset or real capital in social life. Included in social capital is a sense of friendship, mutual sympathy, and social relations and cooperation are closely between individuals and families who form a social group. Social capital has many functions, one of which is to make it easier for people to do things in society.

Social capital is a set of actual or potential resources associated with the maintenance of a network that resists longer than the relationships that already institutionalized that originated from the introduction and mutual recognition (Van De Valk, 2008). Bridging social capital tends to bring people from different social domains together. Each of these forms helps to bring together different needs. Binding social capital is something that is good to support specific reciprocity and mobilize solidarity and at the same be a kind of adhesive strongest in maintaining loyalty and strengthen group-specific identities. Bridging relationships are better at linking external assets and for disseminating information (Field, 2010).

This social capital can be seen from the main elements contained in it. in the journal analysis of sociology, basic elements of social capital are, among others: participation in the network, resiprocity (reciprocity or exchange of kindness), trust (confidence or trust), social norms, values, and actions proactive.

Social capital is different from other capital. If human capital can be seen and measured from the knowledge and skills possessed by a person, then social capital can only be felt from the capabilities that arise from general trust in a society or its parts .

One of the theories in social network analysis is the theory developed by Granovetter, namely Strength weak ties (weak network strength) in 1973. The initial assumption of this theory is how the relationship of a network is built from weak ties and obtained from a friend. ( strong ties ), then wider opportunities to get jobs from acquaintances (weak ties ) than friends ( strong ties ). The theory of Strength of Weak Ties consists of two ties, namely, strong ties and weak 
ties . Strong ties are a (perhaps linear) combination of the amount of time, emotional intensity, closeness (reciprocal trust), and reciprocal service that shape the character of the bond. While weak ties ( weak ties ) are interpersonal ties with closeness that are not so intimate that they can also be referred to as acquaintances (Granovetter, 2001).

Based on the explanation of the popularity, if it is associated with millennial youtubers, the indicator of popularity in this study can be seen from the number of subscribers (followers) and viewers (viewers). The more followers and viewers of YouTube content, it can be said that the YouTuber is more popularer.

Putnam (Field, 2011) argues that social capital consists of two main elements, namely trust (trust) and network (linking). To explain in more detail about the main elements in social capital, an explanation of the indicators of trust (trust) and linking (network) will be explained

\section{Trust (Trust)}

Fukuyama argues that the most important element in social capital is mutual trust which is the glue for lasting cooperation in community groups. This trust grows and is rooted in the values inherent in the group culture. With trust, people will be able to work together more effectively. As according to James Coleman states that a system formed from mutual trust is a component of social capital as the basis of future obligations and expectations, which Putnam further suggests that trust or a feeling of mutual trust is a source of social capital strength that can maintain sustainability. dynamic economy and effective government performance (Fukuyama, 2010).

Trust is also quite useful for youtubers, especially in the early stages of building their youtube channel. Trust is able to facilitate youtubers to work together and help each other. Mutual trust in others in a community has more hope to be able to participate in solving problems that occur.

A form of the desire to take risks in their social relations are based on feeling confident that the others will do something as expected and will always act in a pattern of action are mutually supportive. At least, that others will not do harm himself and his group (Putnam, 1993). Collective action based on mutual trust will increase community participation in various forms and dimensions, especially in the context of mutual progress .

Confidence (trust) is one of the important elements in the social capital which is a strap between each other so as to create a support solid and durable. The core of trust between humans according to Lawang (in Damsar 2009) there are three interrelated things, namely: Social relations between two or more people. Included in this relationship are institutions, which in this sense are represented by a person. A person believes in a particular institution for its own sake, because the people in that institution act. The expectations contained in the relationship, which if realized will not harm one or both parties, as well as social interactions that allow the relationship and hope to be realized.

With third base, the trust is meant here will point to the relationship between two or more parties that contain expectation that favorable one one or both sides.

\section{Linking (Network)}

Social network is one element of social capital, where the network is used as a resource to get something in the social environment through social relationships. Networks have an important role in a person's social capital as stated by Bourdieu, social capital represents an aggregate of actual or potential resources associated with enduring network ownership. each other.

A social network is a group of people who have informal norms or values in addition to the norms or values required for ordinary transactions in the market (Fukuyama, 2005). Agusyanto 
(2007) states that the social network is a special type of network, in which the bond " y ang connect one point to another in the network is a social relationship. Based on this type of bond, then directly or indirectly the members of a social network are humans. He also completes the definition of a social network, social relations can be seen as something that seems to be a path or channel that connects one person (point) with other people through which something can flow.

It it can be applied in a group or community of youtuber in Makassar, where they have the same goal of providing video-video that entertains and is also beneficial for the community. From the results of the research that has been done, it is not uncommon for YouTubers to use network social capital as an effort to develop or increase their popularity, in this case increasing the number of subscribers and viewers.

It can be drawn a definition of social network, which is a social relationship that involves a group of people with informal values or norms in addition to the values or norms needed to be able to connect people who are seen as points and social relationships are seen as a channel. to flow something. Network analysis also says that individuals can manipulate networks to achieve certain goals. Individuals seek and create networks with other individuals to achieve certain goals. This network is used as a channel to get something whether it is in the form of goods or services from other individuals. Not only individuals can manipulate the network they have, but also networks can impact or manipulate the behavior of someone in a group. This may happen because when someone joins a social group, then he will follow the behavior of the group as an adaptation effort to be accepted by the group. (Granovetter, 2001).

\section{Methods}

This study uses a qualitative approach with a case study method. The case that will be observed in this study is about how youtubers in Makassar city utilize social capital, especially social capital trust and linking, in increasing their popularity. John W. Creswell defines qualitative research as a method used to elaborate and understand the meaning ascribed to social or humanitarian problems. The qualitative research process according to Creswell involves important efforts, which include asking questions and procedures, collecting specific data from the research subject, analyzing data inductively from specific themes to general themes, and interpreting the meaning of the data. The final report of this research has a flexible structure or framework. The research conducted qualitatively is a research perspective that is inductive style, focuses on individual meaning, and translates the complexity of a problem Harrison et al., 2017)

This qualitative research aims to explore as much information as possible about the social capital of YouTubers in increasing their popularity. Where the indicator of its popularity is the number of YouTube subscribers and viewers. This research also uses a case study approach . According to Usman and Purnomo (2011) case research or case study intends to study intensively about the background of the current situation and social interactions, individuals, groups, institutions and society.

Creswell argues that a case study is an in-depth exploration of an activity, event, process or individual based on extensive data collection. Case studies are divided into three types, namely historical case studies, observational case studies and biographical case studies. In this study, the observation case study approach is used, namely the study prioritizes observation and participation as a data collection technique, meaning that the observed data are current data. For this reason, researchers must participate in the activities observed (Indrawan, 2014).

This research was conducted in Makassar City, South Sulawesi Province. The research location was chosen with the consideration that Makassar City is one of the meeting cities for many

Copyright $\odot$ 2021, Journal of Asian Multicultural Research for Social Sciences Study, Under the license CC BY-SA 4.0 
Millennial generations. Starting from those whose goal is to continue their education, to some who go to Makassar City in the hope of getting a job. In this study, the research informants are millennial youtubers who live in the city of Makassar. Furthermore, the researcher can then determine the research informants who are the sources for the benefit of obtaining information, using purposive sampling informant withdrawal techniques. Informant withdrawal technique using purposive sampling was chosen because this technique selects informants with various assessments and certain considerations according to the needs of the researcher so that they are considered worthy of being informants. The criteria that the researchers determined were: Have a youtube account and have uploaded videos on youtube, Millennial generation, born in the 1980s -2000s, Domiciled in the city of Makassar, Have a minimum number of subscribers of 1000 subscribers and Have a youtube video that has been watched by 1500 viewers.

The sources of data from this study are: Primary Data, namely the results of observations and interviews with informants, as well as documentation. This data is obtained directly during research and is used as the main data in writing research results. Then secondary data to assist in the preparation of research results are references used in writing both in the form of books, journals, and articles.

The data collection techniques used in this study were: Observations or observations were made on the object or subject of research, not only at the beginning of the study but also during the research. According to Poerwandari (1998), observation is an action taken that leads to accurate observations in order to find and record phenomena that are considered important, and consider the interrelationships between aspects of the phenomenon. Observation in qualitative research according to Poewandari is a natural context (Gunawan, 2014). The researchers observed were about the YouTube content, the number of subscribers and the number of viewers from potential informants. There are several ways that researchers did in this observation, such as opening the youtube channel of prospective informants and observing the number of viewers, comments, likes and subscribers. In addition, researchers are also looking for more comprehensive information on the links Socialblade.Com or Noxinfluencer.com and other related sites. Then the depth Interviews conducted directly, this is done to obtain the views, attitudes and mindset of informants about issues that investigation. In general, the aspects contained in the interviews that the researchers conducted were about the reasons for the informants choosing to become youtubers and how the informants used social capital, especially social capital trust and linking in increasing their popularity.

\section{Data Analysis}

The data analysis technique used in this study is a narrative description that was coined in the form of narrative text, but in order for the presentation of the data to be more comprehensive, it is possible that it will be accompanied by a chart or schema, as well as drawing conclusions). and verification is the result of a finding that has never existed. This finding can be in the form of a description or description of the phenomenon under study, these findings are expected to answer things that were previously unclear so that they become clear, can be in the form of causal or interactive relationships, hypotheses or theories.

In this study, the data validity test method used is the data credibility test which according to Sugiyono (2013) includes the following: Extended Observation is the researcher returning to the field to deepen the data, re-observe and interview with the source again. Using reference material is the existence of supporters to prove the data that has been found by the researcher. For example, interview data needs to be supported by the presence of interview recordings, as well as member check which is defined as re-checking the data obtained from the source. 


\section{Result and Discussion}

Informants interviewed in this study amounted to 4 people with various numbers of subscribers. Informants were selected by purposive sampling and used in-depth interview data collection methods with the aim of providing information about the focus of the research.

Table 1. Characteristics of Informants

\begin{tabular}{|c|l|c|c|c|}
\hline Name & $\begin{array}{c}\text { Age } \\
\text { (Years) }\end{array}$ & $\begin{array}{c}\text { Youtube } \\
\text { Channel }\end{array}$ & $\begin{array}{c}\text { Amount } \\
\text { Subscriber } \\
\text { (Researcher's } \\
\text { Last Review) }\end{array}$ & Content \\
\hline Irwan & \pm 21 & $\begin{array}{c}\text { Irwan } \\
\text { Revan }\end{array}$ & 4.58 Thousand & Music \\
\hline Nurasint A & \pm 26 & $\begin{array}{c}\text { Queenza } \\
12\end{array}$ & 42.2 Thousand & $\begin{array}{c}\text { Collab, } \\
\text { Business: DIY }\end{array}$ \\
\hline $\begin{array}{c}\text { Ardin } \\
\text { Yahya }\end{array}$ & \pm 24 & $\begin{array}{c}\text { Ardi N } \\
\text { Yahya }\end{array}$ & 2.44 Thousand & $\begin{array}{c}\text { Adventures: } \\
\text { Expedition, } \\
\text { Camping, Etc }\end{array}$ \\
\hline Irwan Miuri & \pm 27 & $\begin{array}{c}\text { Studio } \\
\text { Sky }\end{array}$ & 2.65 Thousand & Sports \\
\hline
\end{tabular}

Source: Researcher Data, 2021

Based on the data on the characteristics of the informants, it is known that the YouTuber ranking based on the YouTube content for Irwan is known.

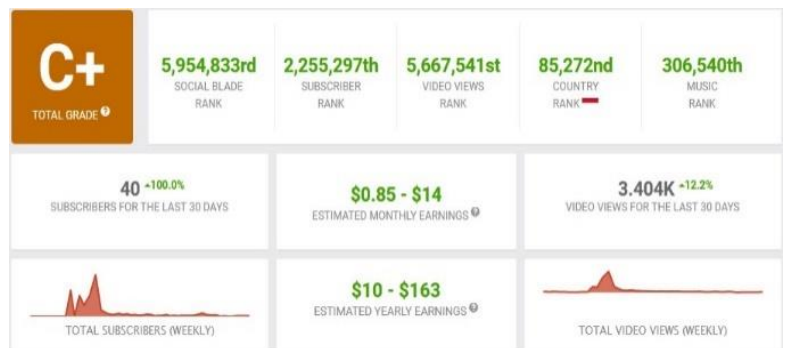

Based on the observation that $\mathrm{Y}$ ou I uber named channel Irwan $\mathrm{K}$ evan be at grade $\mathrm{C}+$ according socialblade.com, where the ratings are seen by YouTuber content, the number of people who viewed the content, the number of followers even to the youtuber rank comes in place. So according to socialblade.com Irwan Revan is ranked $\mathrm{C}+$.

Then for YouTubers with the channel name Quenzaa 12, the position and rating can be seen as follows:

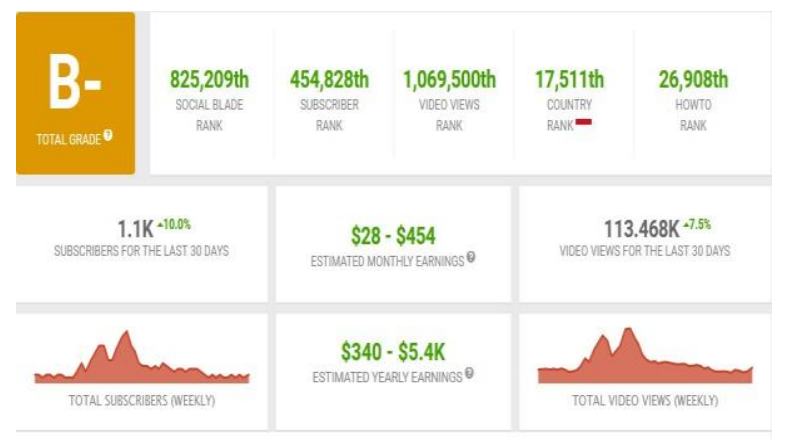


The results of the research carried out show that thanks to the content that is served, such as making crafts, whether he does it himself or involves his students making Nurasinta or whose channel name QUEENZA12 is in grade B- based on socialblade.com , the 26-year-old youtuber started YouTube in December 17, 2014 until now and has had 42.2 thousand subscribers and uploaded 65 videos.

While the third YouTuber with the name Ardin Yahya's youtube channel, is ranked C

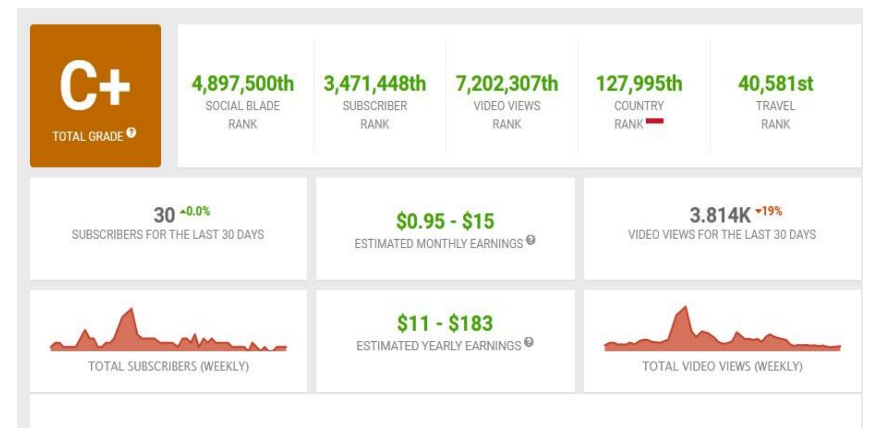

Travel or adventure is the content presented by Ardin Yahya's youtube channel, traveling alone or solo hiking in several mountains in Sulawesi and providing education on his journey. Making this 24-year-old youtuber rank C+ based on socialblade.com, starting YouTube on March 17, 2012 Ardin Yahya already has 2.44 thousand subscribers .

Meanwhile, Studio Langit is a channel that contains content about sports and is ranked B-

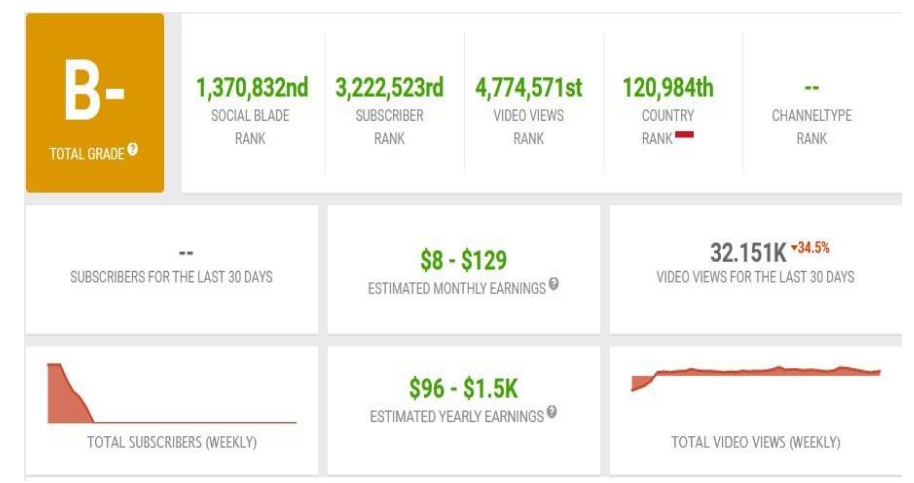

Studio Langit is a channel that contains content about sports and has uploaded 102 videos with a subscriber count of 2.65 thousand, the youtube account formed on December 26, 2019 is ranked B- based on socialblade.com . In addition, socialblade.com also publishes data on the number of subscribers, viewers and income as seen from the activities of the last 30 days when this data was loaded. The following is Studio Langit's activity and income data according to socialblade.com .

Based on the comparison data above between Ardin Yahya, Studio Langit and Irwan Revan. It can be concluded that the highest number of subscribers was obtained by Irwan revan with a total of 4,580 which is quite a significant difference with the two competitors being compared, but in terms of the number of viewers, Studio Langit got. Both the number of subscribers and viewers will greatly affect the income that YouTubers will get. While in another comparison between Queenza12, Studio Langit and Irwan Revan. The highest number of subscribers was obtained by Queenza12 with a total of 42,200 which is quite a difference when compared to the other two youtubers. On the other hand, Queenza12 also got the same thing as seen from the number of viewers who have watched the content he created and amounted to 3,441,017 . 


\section{Utilization of trust social capital of youtubers in increasing popularity}

Trust can encourage someone to work together with others to bring up productive joint activities or actions. Fukuyama (2010), mentions trust as expectations for regularity, honesty, cooperative behavior that arise from within a community based on the norms shared by members of those communities. In terms of economics, trust is quite useful because it can be relied on to reduce costs, this is because trust creates a person's willingness to place group interests above individual interests. The existence of high-trust will create a strong solidarity that is able to make each individual willing to follow the rules, thus helping to strengthen the sense of togetherness. Trust is also quite useful for youtubers, especially in the early stages of building their youtube channel. Trust is able to facilitate youtubers to work together and help each other. Mutual trust in others in a community has more hope to be able to participate in solving problems that occur.

One of the informants who utilizes trust social capital in increasing their capabilities in the youtube world, which leads to increasing popularity is Nurasinta. The content from the Nurasinta youtube channel is about handicrafts and about the use of used goods. When she started her YouTube channel, Nurasinta didn't really understand how to manage YouTube properly so she could increase her subscribers and viewers. Therefore, Nurasinta wants to learn directly from senior YouTubers in Makassar. until finally Nurasinta was trusted to join the WhatsApp group for Makassar YouTubers. From that group, Nurasinta learned a lot about YouTube.

\section{Social capital linking (network) of youtubers in increasing popularity}

Networking or linking in social relations will usually be colored by a distinctive typology in line with the characteristics and orientation of the group. Social groups are usually formed traditionally on the basis of the similarity of hereditary lines ( repeated social experiences ) and the similarity of beliefs on the dimensions of needs ( religious beliefs ) tend to have high cohesiveness, but the range of network and trust that is built is very narrow. Instead the group is built on an equal basis and goal orientation as well as the characteristics of the organization's management that is more modern, would have a level of participation of the members better and has a network range that is more extensive.

It it can be applied in a group or community of youtuber in Makassar, where they have the same goal of providing video-video that entertains and is also beneficial for the community. From the results of research that has been done, it is not uncommon for youtubers to use network social capital as an effort to develop or increase their popularity, in this case increasing the number of subscribers and viewers. One of the informants who interviewed researchers admitted that he didn't need a lot of financial capital to become a YouTuber, only with a cellphone camera. He could make videos to upload to his YouTube channel. which has an important role in the process of developing a youtube channel is a network for example friendship.

The network and its function towards the achievement of a goal cannot be separated from trust. Through the network people know each other, inform each other, remind each other, help each other in implementing or overcoming a problem. Networks are a source of knowledge that is the main basis for strategic trust formation. The most powerful medium for opening a network is socializing in a general sense by opening up through print or electronic media in a limited sense such as association.

Nursinta also uses social network capital in an effort to increase her popularity. Nurasinta is a teacher at an elementary school. According to him, he can use his profession to create content. So once he invited his students to be involved in his videos, of course the video content was

Copyright $\odot$ 2021, Journal of Asian Multicultural Research for Social Sciences Study, Under the license CC BY-SA 4.0 
about handicrafts. The decision to involve students in content must have been through careful consideration, because according to Nurasinta no one is harmed, in fact she can do two things at the same time, namely creating content and staying in the corridor of educating her students to be more creative.

For YouTubers, the benchmark of their popularity can be seen from the number of subscribers and viewers . Subscribers are followers of youtubers who subscribe to the channel of a youtuber who presents their content. In youtube, there are several levels of facilities or awards that youtubers can get if they reach certain points from the number of subscribers determined by youtube. If a channel reached 100 subscribers, the channel gets a facility custom URL on youtube with the name that they want to be the audience of the channel YouTubers more easily find Channel YouTubers do it.

If a channel successfully mencapai 100.000 subscriber, then youtube will give an official award sent directly from the central office of plaque google silver play button. If a channel manages to reach 1,000,000 subscribers, YouTube will give an official award a golden play button plaque. The more subscribers to a channel, the greater the rewards and facilities provided by YouTube. View is one of the segments that becomes the next center of attention of a youtubers. In addition to the existence of a video that will be trending because of a view, this segment also affects the calculation of the income that YouTubers will receive from Google. In the view there is a calculation of the number of views and there is a calculation of how many minutes someone sees a video from a channel. This makes youtubers have a strategy in developing their youtube channel .

\section{Conclusion}

From the results of the study, several conclusions were drawn that trust social capital is widely used by youtubers to increase their popularity, in this case increasing the number of subscribers and viewers on their youtube channel. The social capital of trust that is used is to maximize the performance of the youtuber displaying the videos and watched the quality of contents are generated for the subscriber, viewers and their friends who participated engaged in the development channel its YouTube does not feel betrayed the trust that has been given to these YouTubers. In addition to trust social capital, YouTubers also take advantage of social linking or network capital to increase the number of subscribers and viewers. The social capital of the network used is by utilizing the friendship and community of YouTubers in the process of designing content, taking videos, editing to uploading videos and socializing YouTube channels in order to minimize the cost of managing YouTube channels for YouTubers. Therefore, it is recommended that Youtubers: maximize each video content that is displayed both in terms of video quality, interesting and educational viewing. So that the performances on the trust that have been given can be achieved which leads to popularity. Local Government Agencies: Provide space for work, facilitate access to information for YouTubers so that they can create works that can contribute not only to the region but also to build popularity in a wider area. Makassar society: Over appreciate works of youtuber Makassar with a way to subscribe to channel its YouTube and watch the videos that they upload to broaden the content preferred by the public, but it is expected that other researchers to do research that is more deeply related to social capital the youtuber .

\section{Research Limitations}

To become a famous Youtuber, it is necessary to have trust . The use of trust in increasing popularity is also built by YouTubers in conjunction with viewers in every video he uploads, in order to gain more trust from the audience and also of course affect the continuity of the videos he uploads, but there are still many YouTubers who lack trust in videos. uploaded. Then 
viewed in terms of networking or linking, where from the results of research that has been carried out on average, YouTubers use network social capital as an effort to develop or increase their popularity. This research was not carried out in detail due to the covid 19 pandemic that hit Indonesia, especially in the city of Makassar, therefore the limitations in this study were only showing 4 selected YouTubers or informants, besides that there was no free space for following the content displayed. . So expect future studies to be able to add some informants or youtober and increase of social capital variables studied apart from the researcher to focus on the social capital of trust (confidence) and linking (networking) .

\section{Acknowledgment}

The completion of the writing of this scientific paper was due to the assistance from various parties, especially the researchers addressed to both parents, in addition to the assistance and direction from the supervisors and examiners on campus, as well as YouTubers and fellow lectures who also motivated starting from collecting data until the completion of this thesis writing. Hopefully all the help given from various parties is given a double reward by Allah Subhanahu Wataalah, and hopefully this research will be useful for many people. Amen

\section{References}

Agusyanto, R. (2007). Social Networks in Organizations. Jakarta: King Grafindo.

Corrêa, S. C. H., Soares, J. L., Christino, J. M. M., de Sevilha Gosling, M., \& Gonçalves, C. A. (2020). The influence of YouTubers on followers' use intention. Journal of Research in Interactive Marketing.

Damsar. (2009). Introduction to Economic Sociology, Jakarta: Kencana Prenata Media Group.

Field, J. (2011). Social Capital (Translation: Nurhadi). Yogyakarta: Discourse Creation.

Fukuyama, F. (2005). The Great Shock: Human Nature and The New Social Order. Jakarta: Gramedia Pustaka Utama.

Fukuyama, F. (2010). Trust: Social Virtue and Prosperity Creation. Yogyakarta: Qalam

Giles, D. C. (2018). The Popularity and Appeal of YouTubers:'Authenticity'and 'Ordinariness'. In Twenty-First Century Celebrity: Fame In Digital Culture. Emerald Publishing Limited.

Granovetter, M. (2001). The Strength of Weak Ties. Chicago: University of Chicago Press.

Harrison, H., Birks, M., Franklin, R., \& Mills, J. (2017). Case study research: Foundations and methodological orientations. In Forum Qualitative Sozialforschung/Forum: Qualitative Social Research (Vol. 18, No. 1).

Indrawan, R., \& Yaniawati, R. P. (2014). Metodologi Penelitian Kualitatif, dan Campuran Untuk Manajemen, Pembangunan, dan Pendidikan, Bandung. Penerbit PT Refika Aditama.

Leech, N. L., \& Onwuegbuzie, A. J. (2007). An array of qualitative data analysis tools: A call for data analysis triangulation. School psychology quarterly, 22(4), 557.

Purwandi, L., \& Ali, H. (2017). Milenial Nusantara. PT Gramedia Pustaka Utama.

Van De Valk, L. J. (2008). Leadership development and social capital: Is there a relationship. Journal of leadership education, 7(1), 47-64. 